\title{
Infrared brazing of $\mathrm{Ti}_{50} \mathrm{Al}_{50}$ and $\mathrm{Ti}-6 \mathrm{Al}-4 \mathrm{~V}$ using two Ti-based filler metals
}

\author{
R.K. Shiue, S.K. Wu*, Y.T. Chen, C.Y. Shiue \\ Department of Materials Science and Engineering, National Taiwan University, Taipei 106, Taiwan
}

\section{A R T I C L E I N F O}

\section{Article history:}

Received 22 February 2008

Received in revised form 2 June 2008

Accepted 19 June 2008

\section{Keywords:}

A. Titanium aluminides, based on TiAl

B. Bonding

C. Joining

F. Electron microscopy, scanning

G. Aerospace constructional uses

\begin{abstract}
A B S T R A C T
Infrared brazing of $\mathrm{Ti}_{50} \mathrm{Al}_{50}$ and $\mathrm{Ti}-6 \mathrm{Al}-4 \mathrm{~V}$ using $\mathrm{Ti}-15 \mathrm{Cu}-25 \mathrm{Ni}$ and $\mathrm{Ti}-15 \mathrm{Cu}-15 \mathrm{Ni}$ braze alloys has been conducted. The joint mainly consists of Ti-rich, $\mathrm{Ti}_{2} \mathrm{Ni}$ and interfacial $\mathrm{Ti}_{3} \mathrm{Al}$ phases. The amount of $\mathrm{Ti}_{2} \mathrm{Ni}$ is decreased with increasing the brazing temperature and/or time due to the diffusion of $\mathrm{Ni}$ from the braze alloy into the Ti-6Al-4V substrate during brazing. In contrast, the thickness of interfacial $\mathrm{Ti}_{3} \mathrm{Al}$ phase is insensitive to infrared brazing conditions. The interfacial $\mathrm{Ti}_{3} \mathrm{Al}$ is primarily formed during the cooling cycle of brazing due to limited solubilities of $\mathrm{Al}, \mathrm{Cu}$ and $\mathrm{Ni}$ in $\alpha$-Ti. The presence of both $\mathrm{Ti}_{2} \mathrm{Ni}$ and interfacial $\mathrm{Ti}_{3} \mathrm{Al}$ phases deteriorates shear strength of the joint. The specimen using $\mathrm{Ti}-15 \mathrm{Cu}-15 \mathrm{Ni}$ braze alloy demonstrates the best bonding strength of the joint infrared brazed at $970{ }^{\circ} \mathrm{C}$ above $600 \mathrm{~s}$.
\end{abstract}

(c) 2008 Elsevier Ltd. All rights reserved.

\section{Introduction}

The demand of advanced structural alloys for aerospace and automotive applications has pushed the development of intermetallic compounds [1,2]. Compared to titanium alloys, TiAlbased intermetallics are featured with low density, high specific strength, stiffness and creep strength at elevated temperatures [3,4]. They have been regarded as the potential replacement for titanium alloys in the aircraft compressor. The production cost of TiAl-based intermetallics is high, so bonding of the TiAl-based intermetallic compound and dissimilar structural alloy such as the titanium alloy is crucial in the application of the TiAl-based intermetallics.

Since that the titanium alloy is characterized with high specific strength and excellent corrosion resistance, it is particularly suitable for the aerospace application [5]. Ti-6Al-4V is one of the most important $\alpha-\beta$ titanium alloys, which can be strengthened by proper heat treatments [5]. However, the joining of TiAl-based intermetallics, e.g., $\mathrm{Ti}_{50} \mathrm{Al}_{50}$, and $\mathrm{Ti}-6 \mathrm{Al}-4 \mathrm{~V}$ alloy is difficult due to high reactivity of these alloys. The formation of brittle oxides as well as intermetallic compounds in the joint can cause deterioration of the bonding strength [6-8]. Therefore, great caution must be taken in joining these alloys. For example, the joining process should be performed under a vacuum or protective atmosphere in order to avoid oxygen contamination. Accordingly, vacuum brazing has been considered one of the most promising approaches in brazing these alloys [5].

The selection of brazing filler metals is also important in brazing $\mathrm{Ti}_{50} \mathrm{Al}_{50}$ and $\mathrm{Ti}-6 \mathrm{Al}-4 \mathrm{~V}$. Many Ag-based braze alloys are

\footnotetext{
* Corresponding author. Tel.: +886 22363 7846; fax: +886223634562.

E-mail address: skw@ntu.edu.tw (S.K. Wu).
}

successfully applied in brazing the Ti-based alloys [9-12]. However, most Ag-based braze alloys have low tensile strength and limited creep strength above $400^{\circ} \mathrm{C}$ as compared with the Ti-based braze alloys [7]. In contrast, $\mathrm{Ti}-\mathrm{Cu}-\mathrm{Ni}$ filler foils demonstrate excellent bonding performance in brazing many titanium alloys [13-15]. Both $\mathrm{Ti}-15 \mathrm{Cu}-25 \mathrm{Ni}$ and $\mathrm{Ti}-15 \mathrm{Cu}-15 \mathrm{Ni}$ in $\mathrm{wt} \%$ were chosen to braze $\mathrm{Ti}_{50} \mathrm{Al}_{50}$ and $\mathrm{Ti}-6 \mathrm{Al}-4 \mathrm{~V}$ in the experiment.

Infrared vacuum brazing is characterized by its high heating rate up to $50^{\circ} \mathrm{C} / \mathrm{s}$. It has been proven to be a useful method to investigate the microstructural evolution of the brazed joint in the previous studies $[9,10,14,15]$. Both the microstructural evolution and shear strength of infrared brazed $\mathrm{Ti}_{50} \mathrm{Al}_{50}$ and Ti-6Al-4V joints using two Ti-based braze alloys were evaluated in the study.

\section{Experimental procedures}

The base metals used in the experiment were $\mathrm{Ti}_{50} \mathrm{Al}_{50}$ and Ti-6Al-4V plates with a thickness of $3 \mathrm{~mm}$ each. $\mathrm{Ti}_{50} \mathrm{Al}_{50}$ was prepared by vacuum arc-remelter of high purity (>99.99 wt\%)

Table 1

Summary of infrared brazing variables used in the experiment

\begin{tabular}{lclll}
\hline Filler metal & Brazing time (s)/temp. & $930{ }^{\circ} \mathrm{C}$ & $950{ }^{\circ} \mathrm{C}$ & $970{ }^{\circ} \mathrm{C}$ \\
\hline Ti-15Cu-25Ni & 180 & $\mathrm{M}$ & $\mathrm{M}$ & \\
& 300 & $\mathrm{M}$ & $\mathrm{M}$ & $\mathrm{S} / \mathrm{M}$ \\
& 600 & & & $\mathrm{M}$ \\
& 900 & & & $\mathrm{~S} / \mathrm{M}$ \\
Ti-15Cu-15Ni & 180 & & $\mathrm{M}$ & \\
& 300 & $\mathrm{M}$ & $\mathrm{S} / \mathrm{M}$ \\
& 600 & & & $\mathrm{~S} / \mathrm{M}$ \\
& 1200 & & & $\mathrm{~S} / \mathrm{M}$ \\
\hline
\end{tabular}

S: shear test specimen, M: metallographic specimen. 

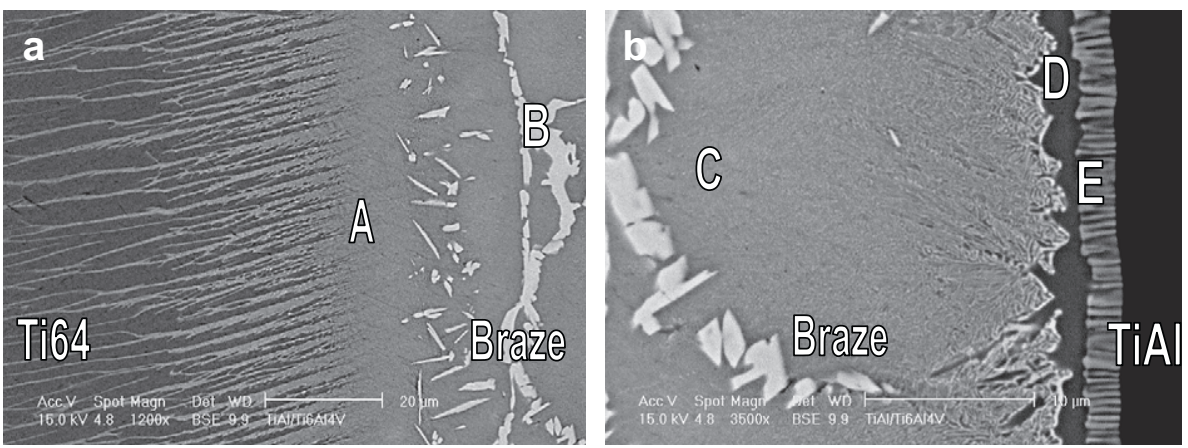

\begin{tabular}{cccccc}
\hline at $\%$ & $\mathrm{~A}$ & $\mathrm{~B}$ & $\mathrm{C}$ & $\mathrm{D}$ & $\mathrm{E}$ \\
\hline $\mathrm{Ti}$ & 71.8 & 60.9 & 72.3 & 70.3 & 45.4 \\
$\mathrm{Ni}$ & 9.8 & 27.0 & 9.0 & 1.2 & 10.3 \\
$\mathrm{Cu}$ & 6.4 & 5.2 & 5.5 & 1.4 & 6.8 \\
$\mathrm{Al}$ & 11.5 & 6.8 & 13.2 & 27.1 & 37.5 \\
$\mathrm{~V}$ & 0.5 & --- & --- & --- & --- \\
phase & Ti-rich & $\mathrm{Ti}_{2} \mathrm{Ni}$ & Ti-rich & $\mathrm{Ti}_{3} \mathrm{Al}$ & --- \\
\hline
\end{tabular}

Fig. 1. SEM BEIs and EDS chemical analysis results of infrared brazed Ti-6Al-4V and $\mathrm{Ti}_{50} \mathrm{Al}_{50}$ using $\mathrm{Ti}-15 \mathrm{Cu}-25 \mathrm{Ni}$ braze alloy at $970{ }^{\circ} \mathrm{C}$ for $300 \mathrm{~s}$.

titanium rods and aluminum pellets. It was repeatedly melted at least six times and the final weight loss of $\mathrm{Ti}_{50} \mathrm{Al}_{50}$ was less than $0.1 \mathrm{wt} \% \mathrm{Ti}_{50} \mathrm{Al}_{50}$ alloy was subsequently homogenized at $1200{ }^{\circ} \mathrm{C}$ for $12 \mathrm{~h}$ in order to reduce the segregation. Both Ti-15Cu-25Ni and Ti-15Cu-15Ni foils in wt\% with, of $50 \mu \mathrm{m}$ thick were used as the brazing filler metals. The heating rate used in infrared brazing was set at $26^{\circ} \mathrm{C} / \mathrm{s}$ throughout the experiment and all samples were preheated at $800^{\circ} \mathrm{C}$ for $300 \mathrm{~s}$ before being heated up to the brazing temperature. Table 1 summarizes all infrared vacuum brazing variables used in the experiment.

The cross-section of the infrared brazed specimen was cut and examined using a Philips XL-30 scanning electron microscope (SEM) with an accelerating voltage of $20 \mathrm{kV}$. Chemical analyses of various phases in the joint were carried out using an energy dispersive spectroscopy (EDS) with the operation voltage of $15 \mathrm{kV}$ and minimum spot size of $1 \mu \mathrm{m}$.
Shear tests were performed to evaluate the bonding strength of selected infrared brazed joints [10,12]. A Shimadzu AG-10 universal testing machine compressed the infrared brazed specimen with a constant speed of $1.7 \times 10^{-2} \mathrm{~mm} / \mathrm{s}$. The experimental data were averaged from at least two measurements of each brazing condition. The fractured surface after the shear test was inspected using an SEM and the cross-section of the brazed joint was also observed in order to identify the fracture location.

\section{Results and discussion}

\subsection{Infrared brazing of $\mathrm{Ti}_{50} \mathrm{Al}_{50}$ and $\mathrm{Ti}-6 \mathrm{Al}-4 \mathrm{~V}$ with $\mathrm{Ti}-15 \mathrm{Cu}-25 \mathrm{Ni}$ braze alloy}

Fig. 1 shows SEM backscattered electron images (BEIs) and EDS chemical analysis results in atomic percent of infrared brazed
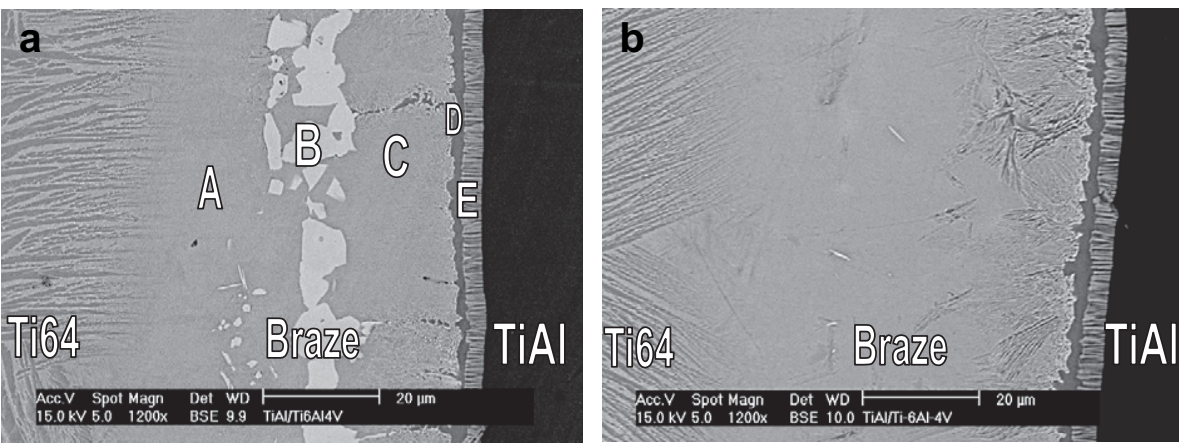

\begin{tabular}{rccccc}
\hline at $\%$ & $\mathrm{~A}$ & $\mathrm{~B}$ & $\mathrm{C}$ & $\mathrm{D}$ & $\mathrm{E}$ \\
\hline $\mathrm{Ti}$ & 72.3 & 60.3 & 69.0 & 66.6 & 47.8 \\
$\mathrm{Ni}$ & 8.1 & 25.2 & 7.9 & 1.8 & 10.3 \\
$\mathrm{Cu}$ & 5.8 & 10.9 & 7.7 & 2.2 & 8.6 \\
$\mathrm{Al}$ & 12.4 & 3.6 & 15.4 & 29.4 & 33.3 \\
$\mathrm{~V}$ & 1.4 & --- & --- & --- & -- \\
phase & Ti-rich & $\mathrm{Ti}_{2} \mathrm{Ni}$ & Ti-rich & $\mathrm{Ti}_{3} \mathrm{Al}$ & --- \\
\hline
\end{tabular}

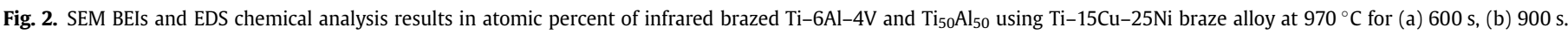



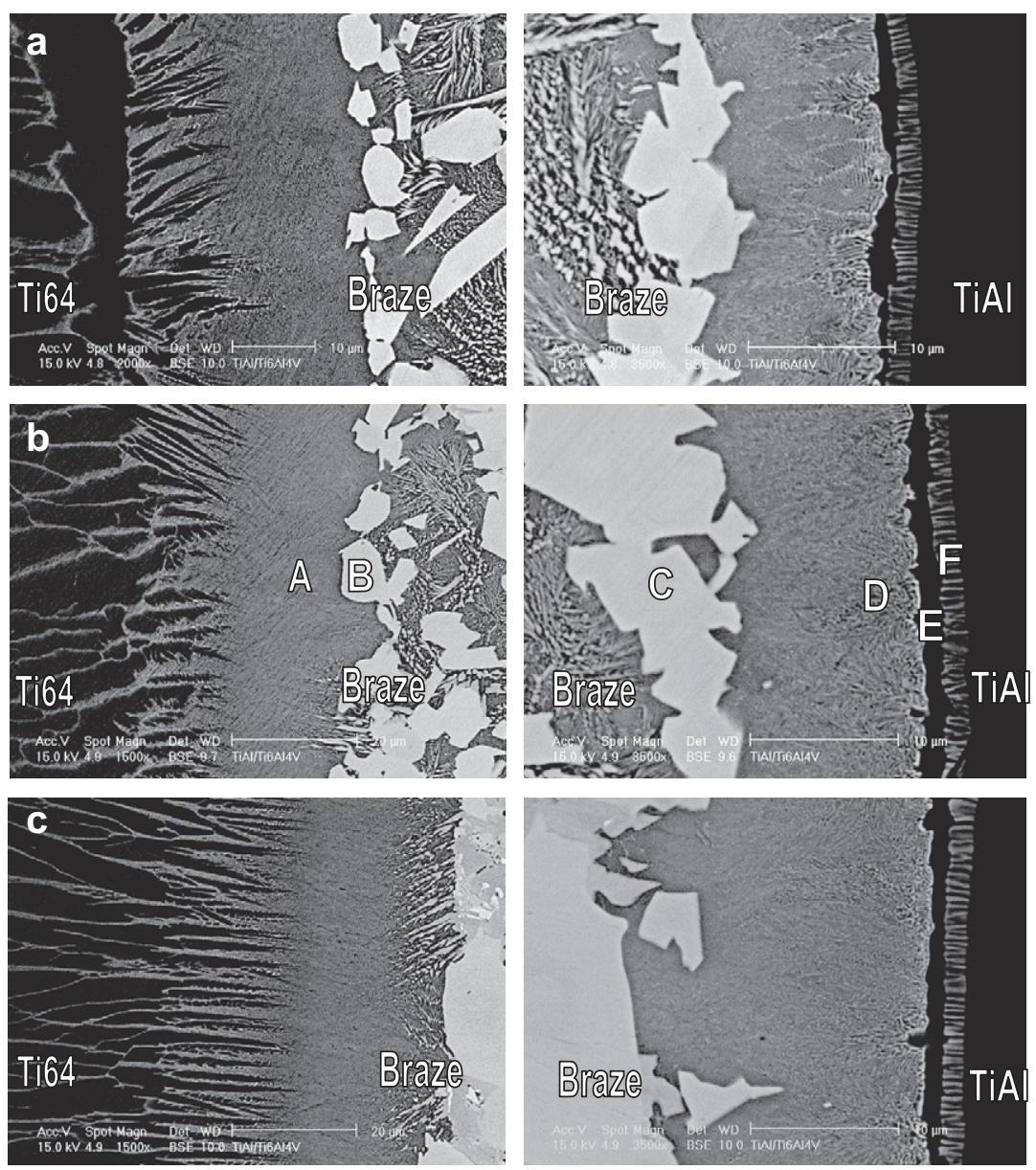

\begin{tabular}{ccccccc}
\hline at $\%$ & $\mathrm{~A}$ & $\mathrm{~B}$ & $\mathrm{C}$ & $\mathrm{D}$ & $\mathrm{E}$ & $\mathrm{F}$ \\
\hline $\mathrm{Ti}$ & 75.4 & 63.4 & 63.7 & 70.1 & 72.6 & 50.4 \\
$\mathrm{Ni}$ & 8.1 & 27.9 & 29.0 & 9.3 & --- & 7.5 \\
$\mathrm{Cu}$ & 4.4 & 5.9 & 5.7 & 5.8 & --- & 3.4 \\
$\mathrm{Al}$ & 10.5 & 2.5 & 1.4 & 14.5 & 27.4 & 38.7 \\
$\mathrm{~V}$ & 1.7 & 0.4 & 0.2 & 0.4 & --- & --- \\
phase & Ti-rich & $\mathrm{Ti}_{2} \mathrm{Ni}$ & $\mathrm{Ti}_{2} \mathrm{Ni}$ & $\mathrm{Ti}-$ rich & $\mathrm{Ti}_{3} \mathrm{Al}$ & --- \\
\hline
\end{tabular}

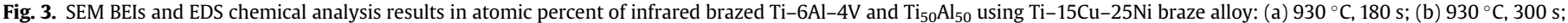
(c) $950{ }^{\circ} \mathrm{C}, 300 \mathrm{~s}$.

$\mathrm{Ti}_{50} \mathrm{Al}_{50}$ and $\mathrm{Ti}-6 \mathrm{Al}-4 \mathrm{~V}$ using the $\mathrm{Ti}-15 \mathrm{Cu}-25 \mathrm{Ni}$ foil at $970{ }^{\circ} \mathrm{C}$ for $300 \mathrm{~s}$. The infrared brazed joint is primarily composed of Ti-rich phase alloyed with $\mathrm{Ni}, \mathrm{Cu}$ and $\mathrm{Al}$ as marked by $\mathrm{A}$ and $\mathrm{C}$ in the figure. Based on the Ni-Ti binary alloy phase diagram, the stoichiometric ratio of $\mathrm{Ti}$ and $\mathrm{Ni}$ in the white phase, as marked by $\mathrm{B}$ is close to $\mathrm{Ti}_{2} \mathrm{Ni}$ [16]. The interfacial morphology between Ti-6Al-4V and the braze alloy is quite different from that between $\mathrm{Ti}_{50} \mathrm{Al}_{50}$ and the braze alloy. The interface between Ti-6Al-4V and the braze alloy is free from a continuous reaction layer. In contrast, a continuous $\mathrm{Ti}_{3} \mathrm{Al}$

Table 2

Data from Ti-Cu and Ti-Ni binary phase diagrams [16]

\begin{tabular}{lll}
\hline Alloy system & $\mathrm{Ti}-\mathrm{Cu}$ & $\mathrm{Ti}-\mathrm{Ni}$ \\
\hline Solidification type & Peritectic & Eutectic \\
Eutectoid reaction & $\beta=\alpha+\mathrm{Ti}_{2} \mathrm{Cu}$ & $\beta=\alpha+\mathrm{Ti}_{2} \mathrm{Ni}$ \\
Eutectoid temperature & $790{ }^{\circ} \mathrm{C}$ & $765{ }^{\circ} \mathrm{C}$ \\
Eutectoid composition & 5.4 at\% & 4.5 at $\%$ \\
Maximum solubility in $\alpha-\mathrm{Ti}$ & 1.6 at $\%$ & 0.2 at $\%$ \\
Maximum solubility in $\beta-\mathrm{Ti}$ & 13.5 at\% & 10 at\% \\
\hline
\end{tabular}

phase as marked by D was identified from the EDS chemical analysis result.

It is noted that there is a lamellar phase between $\mathrm{Ti}_{3} \mathrm{Al}$ and $\mathrm{Ti}_{50} \mathrm{Al}_{50}$ substrates. In the compositional range with $\mathrm{Al}$ between 34 at\% and 50 at\%, Ti-Al alloys form a two-phase equilibrium between $\mathrm{Ti}_{3} \mathrm{Al}\left(\alpha_{2}\right)$ and $\mathrm{Ti}_{50} \mathrm{Al}_{50}(\gamma)$, and usually consist of an $\alpha_{2} / \gamma / \alpha_{2}$ lamellar structure [17]. Although the chemical composition of the lamellar phase in Fig. 1 cannot be accurately determined due to the limited resolution of EDS analysis, the lamellar phase as marked by E contains $\mathrm{Cu}$ and $\mathrm{Ni}$. It is deduced that the lamellar structure is formed during cooling cycle of the infrared brazing.

Fig. 2 shows SEM BEIs and EDS chemical analysis results in atomic percent of infrared brazed $\mathrm{Ti}_{50} \mathrm{Al}_{50}$ and $\mathrm{Ti}-6 \mathrm{Al}-4 \mathrm{~V}$ specimens at $970{ }^{\circ} \mathrm{C}$ for $600 \mathrm{~s}$ and $900 \mathrm{~s}$, respectively. Phases in the brazed joint are similar to those of Fig. 1. The amount of $\mathrm{Ti}_{2} \mathrm{Ni}$ phase is decreased with increasing the brazing time, and the infrared brazed joint for $900 \mathrm{~s}$ is free from $\mathrm{Ti}_{2} \mathrm{Ni}$ phase, as demonstrated in Fig. 2(b). Based on the result of previous study in brazing Ti-6Al-4V and $\mathrm{Ti}-15-3$ alloys using $\mathrm{Ti}-\mathrm{Cu}-\mathrm{Ni}$ fillers, the presence of white $\mathrm{Ti}_{2} \mathrm{Ni}$ phase quickly diminished as the brazing time increases and 

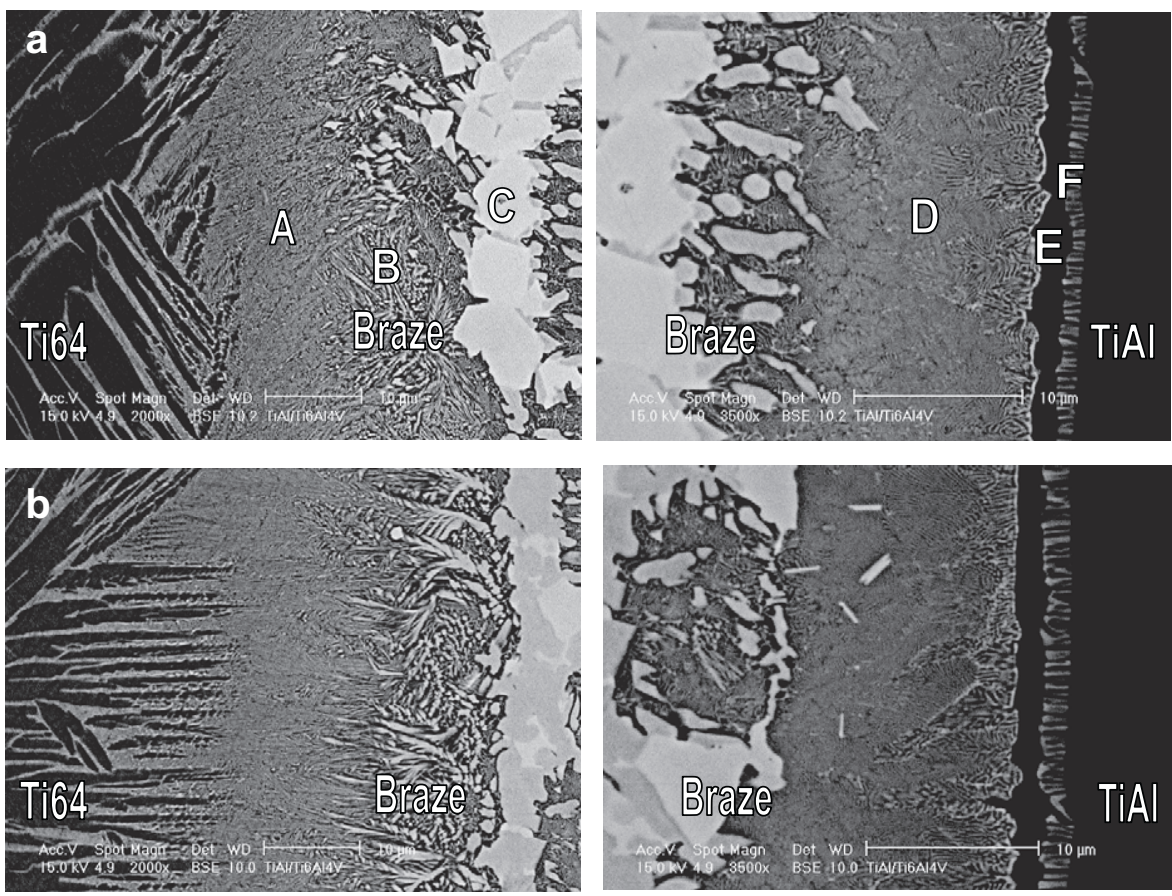

\begin{tabular}{ccccccc}
\hline at $\%$ & $\mathrm{~A}$ & $\mathrm{~B}$ & $\mathrm{C}$ & $\mathrm{D}$ & $\mathrm{E}$ & $\mathrm{F}$ \\
\hline $\mathrm{Ti}$ & 81.6 & 76.2 & 65.7 & 70.8 & 72.0 & 45.6 \\
$\mathrm{Ni}$ & 6.4 & 8.0 & 27.6 & 7.7 & --- & 7.8 \\
$\mathrm{Cu}$ & 3.7 & 8.9 & 6.7 & 8.7 & 1.7 & 7.5 \\
$\mathrm{Al}$ & 8.3 & 6.9 & --- & 12.8 & 26.3 & 39.1 \\
$\mathrm{~V}$ & --- & --- & --- & --- & --- & --- \\
phase & Ti-rich & Ti-rich & $\mathrm{Ti}_{2} \mathrm{Ni}$ & Ti-rich & $\mathrm{Ti}_{3} \mathrm{Al}$ & --- \\
\hline
\end{tabular}

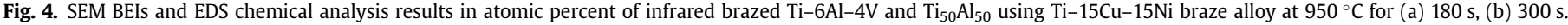

the Ti-rich phase eventually dominates the entire brazed joint [14]. It is in accordance with our experimental observation.

Fig. 3 displays SEM BEIs and EDS chemical analysis results in atomic percent of infrared brazed $\mathrm{Ti}_{50} \mathrm{Al}_{50}$ and $\mathrm{Ti}-6 \mathrm{Al}-4 \mathrm{~V}$ specimens under various brazing conditions. The amount of $\mathrm{Ti}_{2} \mathrm{Ni}$ in Fig. 3 is much more than that in Figs. 1 and 2. Decreasing the brazing temperature and/or time result in huge blocky $\mathrm{Ti}_{2} \mathrm{Ni}$ intermetallic phase in the infrared brazed joint. By contrast, the
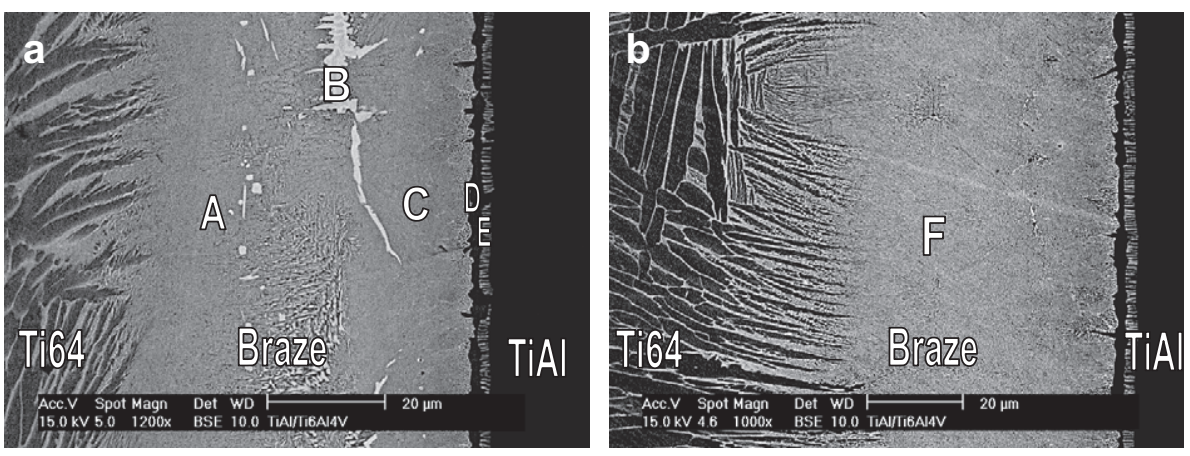

\begin{tabular}{ccccccc}
\hline at $\%$ & $\mathrm{~A}$ & $\mathrm{~B}$ & $\mathrm{C}$ & $\mathrm{D}$ & $\mathrm{E}$ & $\mathrm{F}$ \\
\hline $\mathrm{Ti}$ & 78.6 & 64.2 & 71.5 & 70.8 & 49.5 & 76.8 \\
$\mathrm{Ni}$ & 5.7 & 11.4 & 7.5 & 1.2 & 5.5 & 7.2 \\
$\mathrm{Cu}$ & 5.1 & 20.5 & 8.7 & 1.1 & 4.8 & 6.2 \\
$\mathrm{Al}$ & 8.5 & 3.7 & 12.3 & 26.9 & 40.2 & 9.6 \\
$\mathrm{~V}$ & 2.1 & 0.2 & --- & --- & --- & 0.3 \\
phase & Ti-rich & $\mathrm{Ti}_{2} \mathrm{Ni}$ & Ti-rich & $\mathrm{Ti}_{3} \mathrm{Al}$ & --- & Ti-rich \\
\hline
\end{tabular}

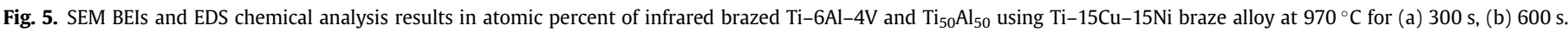


Table 3

Average shear strengths of infrared brazed Ti-6Al-4V and $\mathrm{Ti}_{50} \mathrm{Al}_{50}$ specimens

\begin{tabular}{llcl}
\hline Filler metal & Brazing temperature $\left({ }^{\circ} \mathrm{C}\right)$ & Brazing time $(\mathrm{s})$ & $\begin{array}{l}\text { Shear strength } \\
(\mathrm{MPa})\end{array}$ \\
\hline Ti-15Cu-25Ni & 970 & 300 & 189 \\
& 970 & 900 & 214 \\
Ti-15Cu-15Ni & 970 & 300 & 240 \\
& 970 & 600 & 270 \\
& 970 & 1200 & 280 \\
\hline
\end{tabular}

width of interfacial $\mathrm{Ti}_{3} \mathrm{Al}$ phase is less sensitive to infrared brazing conditions such as brazing temperature or time. Hence, the interfacial reaction kinetics among $\mathrm{Ti}_{50} \mathrm{Al}_{50}$, braze alloy and $\mathrm{Ti}-$ $6 \mathrm{Al}-4 \mathrm{~V}$ are quite different in the infrared brazing.

Table 2 summarizes important information from $\mathrm{Ti}-\mathrm{Cu}$ and Ti-Ni binary alloy phase diagrams [16]. Maximum solubilities of $\mathrm{Cu}$ and $\mathrm{Ni}$ in $\beta$-Ti are much more than those in $\alpha$-Ti. Moreover, the solubility of $\mathrm{Al}$ in both $\alpha$ - and $\beta$-Ti is greatly decreased with decreasing the temperature [16]. $\mathrm{Ti}_{50} \mathrm{Al}_{50}$ substrate is readily dissolved into the molten braze, and thus there is no interfacial $\mathrm{Ti}_{3} \mathrm{Al}$ layer to formed at the infrared brazing temperature. It is deduced that the formation of interfacial $\mathrm{Ti}_{3} \mathrm{Al}$ phase is primarily resulted from the cooling cycle of brazing due to limited solubilities of $\mathrm{Al}$ in the $\alpha$-Ti at low temperatures. Therefore, the variation of brazing conditions, e.g., brazing time and temperature, places minor effect on the thickness of the continuous $\mathrm{Ti}_{3} \mathrm{Al}$ layer between the braze alloy and $\mathrm{Ti}_{50} \mathrm{Al}_{50}$ substrate.

On the other hand, the presence of $\mathrm{Ti}_{2} \mathrm{Ni}$ intermetallic compound in the brazed joint is strongly related to both the dissolution of Ti-6Al-4V substrate into the molten braze and the diffusive transport of $\mathrm{Ni}$ atoms into the $\mathrm{Ti}-6 \mathrm{Al}-4 \mathrm{~V}$ substrate. Its presence is also tightly connected to the infrared brazing conditions, i.e., brazing temperature and time. In addition, phase transformation of Ti alloys during the infrared brazing has to be taken into consideration so as to unveil the microstructural evolution of brazed joints. According to Table 2, both solubilities of $\mathrm{Cu}$ and $\mathrm{Ni}$ in $\beta$-Ti are much higher than those in $\alpha$-Ti. Since brazing temperatures used in the experiment are higher than the invariant temperatures of $\mathrm{Ti}-\mathrm{Cu}$ and $\mathrm{Ti}-\mathrm{Ni}$, the decompositions of $\beta$-Ti are inevitable during the cooling of infrared brazed joints. For example, the eutectoid decomposition of beta titanium: $\beta-\mathrm{Ti} \rightarrow \alpha-\mathrm{Ti}+\mathrm{Ti}_{2} \mathrm{Ni}$ is completed after infrared brazing. Both $\mathrm{Ti}_{2} \mathrm{Ni}$ and acicular $\alpha$-Ti are observed in Figs. 1-3.

The chemical composition of $\mathrm{Ti}-15 \mathrm{Cu}-25 \mathrm{Ni}$ in atomic percent is $12.3 \% \mathrm{Cu}, 22.2 \% \mathrm{Ni}$ and balance $\mathrm{Ti}$. Both $\mathrm{Cu}$ and $\mathrm{Ni}$ act as the melting point depressants in Ti-based braze alloys [6-8]. The existence of $\mathrm{Ti}_{2} \mathrm{Ni}$ in the brazed joint is highly related to the distribution of $\mathrm{Ni}$ content in the joint. Diffusive transport of Ni from the molten braze alloy into the $\beta$-Ti of Ti-6Al-4V substrate during infrared brazing results in the depletion of $\mathrm{Ni}$ from the braze alloy. Because the amount of $\mathrm{Ti}_{2} \mathrm{Ni}$ in the brazed joint is decreased with increasing the brazing time, the joint infrared brazed at $970{ }^{\circ} \mathrm{C}$ for $900 \mathrm{~s}$ is lack of $\mathrm{Ti}_{2} \mathrm{Ni}$ intermetallic compound. It is unusual in brazing that a stable intermetallic compound can be completely eliminated from the joint with the aid of using a longer thermal history.

\subsection{Infrared brazing of $\mathrm{Ti}_{50} \mathrm{Al} \mathrm{l}_{50}$ and $\mathrm{Ti}-6 \mathrm{Al}-4 \mathrm{~V}$ with $\mathrm{Ti}-15 \mathrm{Cu}-15 \mathrm{Ni}$ braze alloy}

Fig. 4 shows SEM BEIs and EDS chemical analysis results in atomic percent of infrared brazed $\mathrm{Ti}_{50} \mathrm{Al}_{50}$ and $\mathrm{Ti}-6 \mathrm{Al}-4 \mathrm{~V}$ using Ti-15Cu-15Ni braze alloy at $950{ }^{\circ} \mathrm{C}$ for $180 \mathrm{~s}$ and $300 \mathrm{~s}$, respectively. Similar to the aforementioned results, the infrared brazed joint mainly consists of Ti-rich and $\mathrm{Ti}_{2} \mathrm{Ni}$ phases. A continuous $\mathrm{Ti}_{3} \mathrm{Al}$ reaction layer is also identified at the interface between the braze alloy and $\mathrm{Ti}_{50} \mathrm{Al}_{50}$.

Fig. 5 shows SEM BEIs and EDS chemical analysis results in atomic percent of infrared brazed joint at $970{ }^{\circ} \mathrm{C}$ for $300 \mathrm{~s}$ and $600 \mathrm{~s}$. The thickness of interfacial $\mathrm{Ti}_{3} \mathrm{Al}$ phase remains almost intact regardless of the increasing brazing temperature and/or time. In contrast, the amount of $\mathrm{Ti}_{2} \mathrm{Ni}$ phase in Fig. 5 significantly decreases, as compared with that in Fig. 4. The Ti-rich phase eventually dominates the entire brazed joint for the specimen infrared brazed at $970{ }^{\circ} \mathrm{C}$ for $600 \mathrm{~s}$ as illustrated in Fig. 5(b). Because the Ni content in $\mathrm{Ti}-15 \mathrm{Cu}-15 \mathrm{Ni}$ is lower than that in $\mathrm{Ti}-15 \mathrm{Cu}-25 \mathrm{Ni}$ braze alloy, the
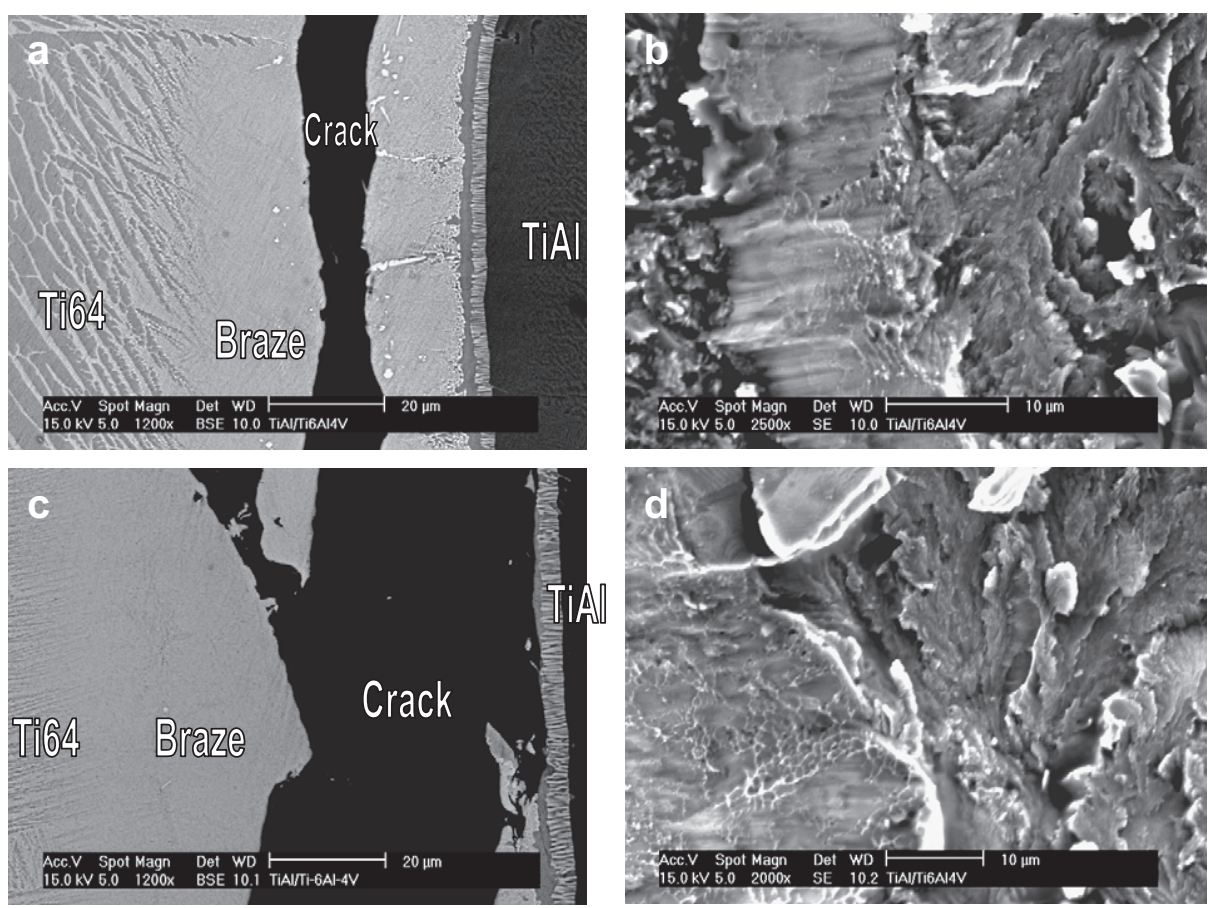

Fig. 6. SEM cross-sections and fractographs of the $\mathrm{Ti}_{50} \mathrm{Al}_{50}$ side after shear tests of the joints using Ti-15Cu-25Ni filler infrared brazed at $970{ }^{\circ} \mathrm{C}$ for $(\mathrm{a}, \mathrm{b}) 300 \mathrm{~s}$, (c,d) $900 \mathrm{~s}$. 

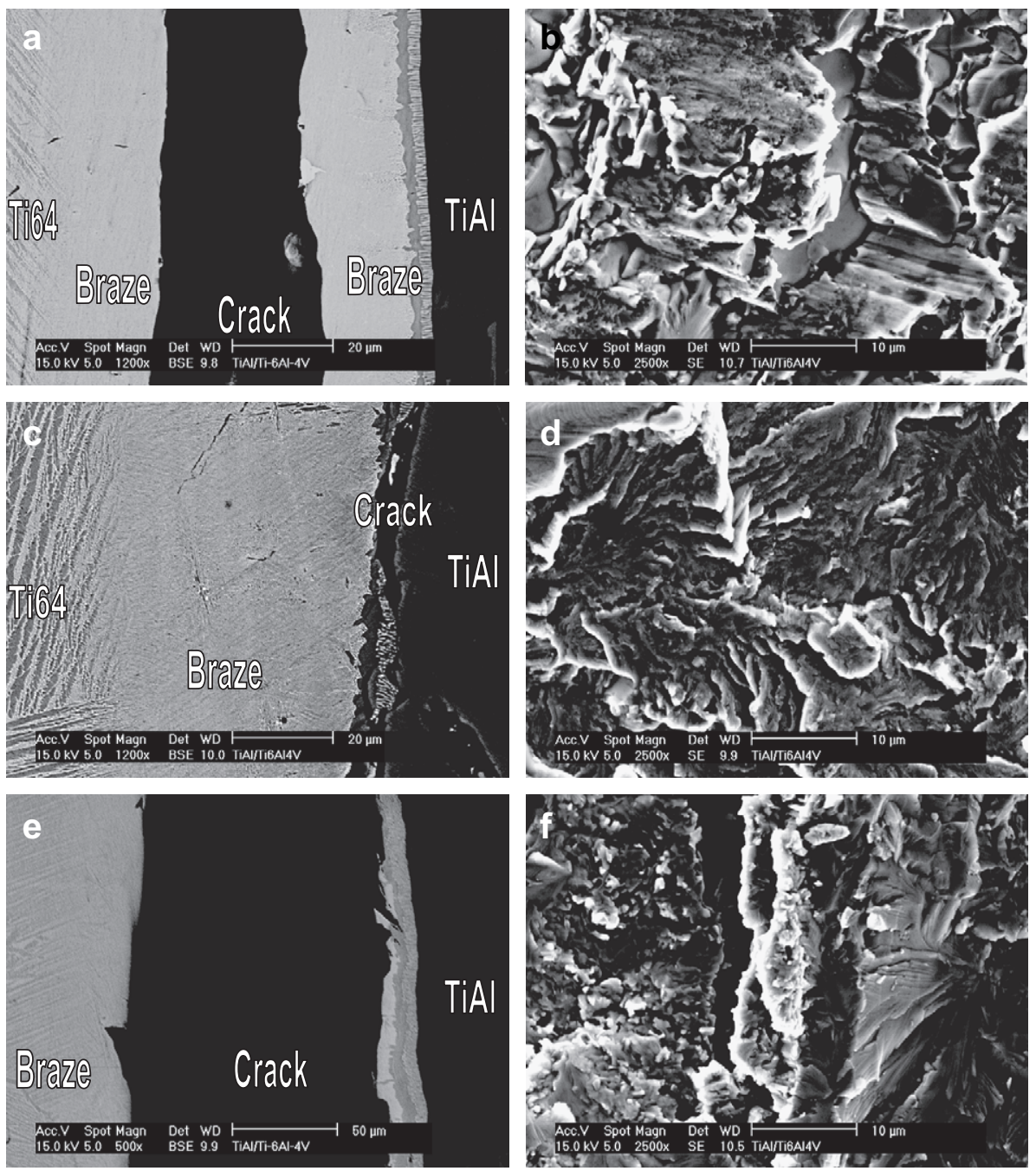

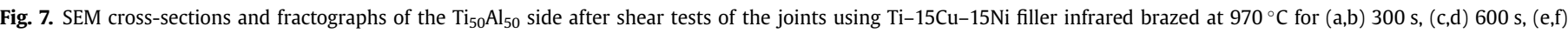
$1200 \mathrm{~s}$.

presence of white $\mathrm{Ti}_{2} \mathrm{Ni}$ phase in the $\mathrm{Ti}-15 \mathrm{Cu}-15 \mathrm{Ni}$ brazed joint quickly diminishes when brazing temperature and/or brazing time increase.

According to the $\mathrm{Cu}-\mathrm{Ni}$-Ti ternary alloy phase diagram, the chemical composition of the initial molten braze moves toward the Ti-rich end in $\mathrm{Cu}-\mathrm{Ni}$-Ti ternary alloy phase diagram during infrared brazing due to the fact that both $\mathrm{Cu}$ and $\mathrm{Ni}$ atoms diffuse from the molten brazing alloy into the $\beta$-Ti substrate [18]. The molten braze is isothermal solidified once $\mathrm{Cu}$ and $\mathrm{Ni}$ are depleted from the braze alloy. Consequently, the amount of white $\mathrm{Ti}_{2} \mathrm{Ni}$ phase in the joint is decreased with increasing the brazing time as illustrated in Fig. 5. In contrast, huge amounts of $\mathrm{Ti}_{2} \mathrm{Ni}$ intermetallic compound are found in the joints infrared brazed at lower temperature due to less depletion of $\mathrm{Ni}$ from the braze alloy as shown in Fig. 4. This phenomenon is in accordance with the previous studies in brazing high-strength titanium alloys [14,15].

\subsection{Shear strength and fractographic observation of infrared brazed $\mathrm{Ti}_{50} \mathrm{Al}_{50}$ and Ti-6Al-4V using Ti-15Cu-25Ni and Ti-15Cu-15Ni braze alloys}

Table 3 illustrates the average shear strength of infrared brazed $\mathrm{Ti}_{50} \mathrm{Al}_{50}$ and $\mathrm{Ti}-6 \mathrm{Al}-4 \mathrm{~V}$ specimens at $970{ }^{\circ} \mathrm{C}$ for $300-1200 \mathrm{~s}$. The average shear strength of infrared brazed joint is increased with increasing the brazing time. The $300 \mathrm{~s}$ infrared brazed specimen using $\mathrm{Ti}-15 \mathrm{Cu}-25 \mathrm{Ni}$ braze alloy demonstrates the lowest shear strength of $189 \mathrm{MPa}$. In contrast, the largest shear strength of $280 \mathrm{MPa}$ is acquired from the $1200 \mathrm{~s}$ brazed specimen using Ti-15Cu-15Ni braze alloy.

Fig. 6(a,c) and (b,d) shows SEM cross-sections and fractographs of the $\mathrm{Ti}_{50} \mathrm{Al}_{50}$ side after shear tests using Ti-15Cu-25Ni filler metal infrared brazed at $970{ }^{\circ} \mathrm{C}$ for $300 \mathrm{~s}$ and $900 \mathrm{~s}$, respectively. For the specimen infrared brazed at $970{ }^{\circ} \mathrm{C}$ for $300 \mathrm{~s}$, the crack initiates and propagates along the brazed joint, especially along the $\mathrm{Ti}_{2} \mathrm{Ni}$ phase. The disappearance of $\mathrm{Ti}_{2} \mathrm{Ni}$ phase from Fig. 6(a) implies its complete fracture in the shear test. The joint has the lowest shear strength of $189 \mathrm{MPa}$ due to the presence of $\mathrm{Ti}_{2} \mathrm{Ni}$ phase. Cleavage fracture is conspicuously observed in Fig. 6(b). It is obvious that the existence of $\mathrm{Ti}_{2} \mathrm{Ni}$ phase is detrimental to shear strength of the joint.

The fracture location is changed from $\mathrm{Ti}_{2} \mathrm{Ni}$ in the braze alloy into interfacial $\mathrm{Ti}_{3} \mathrm{Al}$ phase for the specimen infrared brazed at $970{ }^{\circ} \mathrm{C}$ for $900 \mathrm{~s}$, as illustrated in Fig. 6(c). Quasi-cleavage fracture is found in Fig. 6(d). It is noted that the brazed joint is free from $\mathrm{Ti}_{2} \mathrm{Ni}$ intermetallic compound due to its longer thermal history (Fig. 2(b)). Therefore, increasing the brazing time improves the bonding strength of the joint.

The $\mathrm{Ni}$ content of $\mathrm{Ti}-15 \mathrm{Cu}-15 \mathrm{Ni}$ is lower than that of $\mathrm{Ti}-$ $15 \mathrm{Cu}-25 \mathrm{Ni}$, so the amount of the brittle $\mathrm{Ti}_{2} \mathrm{Ni}$ phase is greatly reduced in the brazed joint. Shear strength of the joint using $\mathrm{Ti}-15 \mathrm{Cu}-15 \mathrm{Ni}$ braze alloy is generally higher than that using 
Ti-15Cu-25Ni filler. Increasing the $\mathrm{Ni}$ content of the braze alloy results in more $\mathrm{Ti}_{2} \mathrm{Ni}$ phase formed in the joint, so lower shear strength of the joint is obtained from the test. Fig. 7(a,c,e) and (b,d,f) displays SEM cross-sections and fractographs of the $\mathrm{Ti}_{50} \mathrm{Al}_{50}$ side after shear tests using Ti-15Cu-15Ni alloy infrared brazed at $970{ }^{\circ} \mathrm{C}$ for $300 \mathrm{~s}, 600 \mathrm{~s}$ and $1200 \mathrm{~s}$, respectively. For the $\mathrm{Ti}-15 \mathrm{Cu}-15 \mathrm{Ni}$ alloy, shear strength of the joint infrared brazed at $970{ }^{\circ} \mathrm{C}$ for $300 \mathrm{~s}$ displays lower shear strength of $240 \mathrm{MPa}$, and the joint is fractured along $\mathrm{Ti}_{2} \mathrm{Ni}$ phase, as illustrated in Fig. 7(a). For specimens infrared brazed at $970{ }^{\circ} \mathrm{C}$ above $600 \mathrm{~s}$, there is no blocky $\mathrm{Ti}_{2} \mathrm{Ni}$ phase in the joint any more. Cracks are initiated from the interfacial $\mathrm{Ti}_{3} \mathrm{Al}$ phase, as shown in Fig. 7(c) and (e), and they demonstrate almost the similar bonding strength in the shear test. Because all fractographs displayed in Fig. 7 are cleavage dominated fracture, both $\mathrm{Ti}_{2} \mathrm{Ni}$ and interfacial $\mathrm{Ti}_{3} \mathrm{Al}$ phases are of inherent brittleness.

According to shear test results, the bonding strength of the joint can be improved by using higher brazing temperature, longer brazing time and by employing the filler metal with lower $\mathrm{Ni}$ content, say $\mathrm{Ti}-15 \mathrm{Cu}-15 \mathrm{Ni}$, in order to avoid or reduce the formation of $\mathrm{Ti}_{2} \mathrm{Ni}$ phase in the brazed joint. However, the stable interfacial $\mathrm{Ti}_{3} \mathrm{Al}$ limits the bonding strength between $\mathrm{Ti}_{50} \mathrm{Al}_{50}$ and $\mathrm{Ti}-6 \mathrm{Al}-4 \mathrm{~V}$ even for the brazed joint without blocky $\mathrm{Ti}_{2} \mathrm{Ni}$ phase. Unfortunately, at present study, the interfacial $\mathrm{Ti}_{3} \mathrm{Al}$ layer cannot be removed from the joint by changing the infrared brazing conditions.

\section{Conclusions}

Microstructural evolution and bonding strength of the infrared brazed $\mathrm{Ti}_{50} \mathrm{Al}_{50}$ and $\mathrm{Ti}-6 \mathrm{Al}-4 \mathrm{~V}$ joint using Ti-15Cu-25Ni and Ti$15 \mathrm{Cu}-15 \mathrm{Ni}$ braze alloys have been evaluated in the study. Primary conclusions are summarized in the following:

1. The joint mainly consists of Ti-rich, $\mathrm{Ti}_{2} \mathrm{Ni}$ and interfacial $\mathrm{Ti}_{3} \mathrm{Al}$ phases. The amount of $\mathrm{Ti}_{2} \mathrm{Ni}$ decreases with increasing the brazing temperature and/or time due to the diffusion of $\mathrm{Ni}$ atoms from the braze alloy into the Ti-6Al-4V substrate. In contrast, the thickness of the interfacial $\mathrm{Ti}_{3} \mathrm{Al}$ phase is insensitive to infrared brazing conditions. The interfacial $\mathrm{Ti}_{3} \mathrm{Al}$ is primarily resulted from the cooling cycle of brazing due to limited solubilities of $\mathrm{Al}$ in $\alpha$-Ti.

2. The average shear strength of infrared brazed joint increases with increasing the brazing time. The $300 \mathrm{~s}$ infrared brazed specimen using $\mathrm{Ti}-15 \mathrm{Cu}-25 \mathrm{Ni}$ braze alloy demonstrates the lowest shear strength of $189 \mathrm{MPa}$. In contrast, the highest shear strength of $280 \mathrm{MPa}$ is acquired from the $1200 \mathrm{~s}$ brazed specimen using $\mathrm{Ti}-15 \mathrm{Cu}-15 \mathrm{Ni}$ braze alloy.

3. The presence of both $\mathrm{Ti}_{2} \mathrm{Ni}$ and interfacial $\mathrm{Ti}_{3} \mathrm{Al}$ phases deteriorates shear strength of the joint. The bonding strength of joint can be improved by using higher brazing temperature, longer brazing time and by employing the filler metal with lower Ni content, say $\mathrm{Ti}-15 \mathrm{Cu}-15 \mathrm{Ni}$, so to avoid or reduce the formation of $\mathrm{Ti}_{2} \mathrm{Ni}$ in the brazed joint. However, the stable interfacial $\mathrm{Ti}_{3} \mathrm{Al}$ layer in between $\mathrm{Ti}-6 \mathrm{Al}-4 \mathrm{~V}$ and $\mathrm{Ti}_{50} \mathrm{Al}_{50}$ confines the bonding strength even for the brazed joint without the brittle $\mathrm{Ti}_{2} \mathrm{Ni}$ phase. In the present study, this layer cannot be removed from the joint by changing infrared brazing conditions.

\section{Acknowledgements}

The authors gratefully acknowledge the financial support of this research by the National Science Council (NSC), Taiwan, Republic of China, under the Grant number NSC 95-2221-E002-081-MY2.

\section{References}

[1] Liu CT. Recent advances in ordered intermetallics. Mater Chem Phys 1995;42: 77-86.

[2] Tetsui T, Ono S. Endurance and composition and microstructure effects on endurance of TiAl used in turbochargers. Intermetallics 1999;7: 689-97.

[3] Liu CT, Maziasz PJ. Microstructural control and mechanical properties of dualphase TiAl alloys. Intermetallics 1998;6:653-61.

[4] Liu CT, Schneibel JH, Maziasz PJ, Wright JL, Easton DS. Tensile properties and fracture toughness of TiAl alloys with controlled microstructures. Intermetallics 1996;4:429-40.

[5] Roger R, Collings EW, Welsch G. Materials properties handbook: titanium alloys. Materials Park: ASM International; 1993.

[6] Olson DL, Siewert TA, Liu S, Edwards GR. ASM handbook. In: Welding, soldering and brazing, vol. 6. Materials Park: ASM International; 1993.

[7] Humpston G, Jacobson DM. Principles of soldering and brazing. Materials Park: ASM International; 1993.

[8] Schwartz M. Brazing: for the engineering technologist. New York: Chapman \& Hall; 1995.

[9] Shiue RK, Wu SK, Chan $\mathrm{CH}$. Infrared brazing $\mathrm{Cu}$ and $\mathrm{Ti}$ using a 95Ag-5Al braze alloy. Metall Mater Trans 2004;35A(10):3177-86.

[10] Shiue RK, Wu SK, Chen SY. Infrared brazing of TiAl intermetallic using BAg-8 braze alloy. Acta Mater 2003;51(7):1991-2004.

[11] Liu CC, Ou CL, Shiue RK. The microstructural observation and wettability study of brazing Ti-6Al-4V and 304 stainless steel using three braze alloys. J Mater Sci 2002;37(11):2225-35.

[12] Tetsui T. Effects of brazing filler on properties of brazed joints between TiAl and metallic materials. Intermetallics 2001;9:253-60.

[13] Wallisa IC, Ubhia HS, Bacosb MP, Jossob P, Lindqvistc J, Lundstromc D, et al. Brazed joints in $\gamma$ TiAl sheet: microstructure and properties. Intermetallics 2004;12:303-16.

[14] Chang CT, Du YC, Shiue RK, Chang CS. Infrared brazing of high-strength titanium alloys by $\mathrm{Ti}-15 \mathrm{Cu}-15 \mathrm{Ni}$ and $\mathrm{Ti}-15 \mathrm{Cu}-25 \mathrm{Ni}$ filler foils. Mater Sci Eng A 2006:420:155-64.

[15] Chang CT, Shiue RK, Chang CS. Microstructural evolution of infrared brazed Ti-15-3 alloy using Ti-15Cu-15Ni and Ti-15Cu-25Ni fillers. Scr Mater 2006; 54(5):853-8.

[16] Massalski TB. Binary alloy phase diagrams. Materials Park: ASM International; 1990.

[17] Yang YS, Wu SK. A study by high-resolution electron microscopy of an $\alpha_{2}+\gamma$ two-phase Ti-40 at.\% Al alloy. Philos Mag 1993;67:463-78.

[18] Villars P, Prince A, Okamoto H. Handbook of ternary alloy phase diagrams. Materials Park: ASM International; 1995. 